\title{
The Quality Problems of the Dammed Water in the Mountain Forest Catchment
}

\author{
Ewa Jachniak ${ }^{1 *}$, Andrzej Jaguś ${ }^{\prime}$, Agata Młyniuk ${ }^{2}$, Barbara Nycz ${ }^{2}$ \\ 1 University of Bielsko-Biala, Willowa 2, 43-309 Bielsko-Biała, Poland \\ 2 Graduate of the University of Bielsko-Biala, Poland \\ * Corresponding author's e-mail: ejachniak@ath.bielsko.pl
}

\begin{abstract}
The research concerned the Wapienica dam reservoir, which is located in the Polish Carpathians, near the city of Bielsko-Biala. The dam closes the flow of water from the $11.1 \mathrm{~km}^{2}$ catchment. The forests cover about $90 \%$ of the catchment area, while the rest of the catchment constitutes grassland areas. The reservoir has a capacity of 1.05 million $\mathrm{m}^{3}$. The collected water is intended for supplying a water supply system. The catchment is treated as semi-natural, because within its borders the only works related to forest management are carried out. The aim of the research was evaluation of the water quality in this reservoir, including trophic status, based on the analyses carried out in 2015. It was found that the water was of good quality in basic physicochemical terms (e.g. suspension $\leq 13 \mathrm{mg} \cdot \mathrm{dm}^{-3}, \mathrm{COD}_{\mathrm{Cr}} \leq 11 \mathrm{mgO} \cdot \mathrm{dm}^{-3}$, conductivity $\leq 82 \mu \mathrm{S} \cdot \mathrm{cm}^{-1}$, phosphates $<0.05 \mathrm{mg} \cdot \mathrm{dm}^{-3}$, nitrates $\leq 5.1 \mathrm{mg} \cdot \mathrm{dm}^{-3}$, dissolved iron $\left.\leq 0.12 \mathrm{mg} \cdot \mathrm{dm}^{-3}\right)$. The contamination with heavy metals was not ascertained, with the exception of the zinc. The assessed sanitary indicators are worse -the bacteria of the Coli group and periodically also enterococci were observed in the reservoir water. The reservoir is not homogeneous in terms of biological production (the trophy degree). It is low in the upper part (oligotrophy generally) and increases in the part near the dam (mesotrophy, also eutrophy). The established presence of dangerous bacteria and symptoms of the reservoir eutrophication are disturbing in the context of the opinion on the purity of uninhabited mountain areas.
\end{abstract}

Keywords: mountain areas, dam reservoir, water quality, water pollution, water trophy

\section{INTRODUCTION}

According to the International Commission's on Large Dams data (http://www.icold-cigb.net; January 2019), there are 59,071 large dam reservoirs in the world. They play various functions, in particular: they are reservoirs of water for agricultural irrigation $(34.7 \%$ of the reservoirs), they pile up water to produce electricity $(16.5 \%)$ and supply water to water supply systems $(12.9 \%)$, they also protect against floods $(12.4 \%)$. The requirements for the quality of water collected in the reservoirs are depended on their intended use. Good quality is desirable primarily in the case of the reservoirs, which are used for water supply purposes, because the water of good quality does not require the complex and expensive treatment processes for food purposes.
The water quality in dam reservoirs usually is not good. In the literature, eutrophic reservoirs (Lugo et al. 1998, Tarkowska-Kukuryk 2013) and the problems related to water pollution and also bottom sediments by different substances (Dabrowski et al. 2014, Cao et al. 2011, Sim et al. 2016) are often described. The factor that adversely affects for water quality is primarily the human activity in the catchment area of the reservoir. Pollution can come from the living activity (Cheung et al. 2003), agricultural activity (Melland et al. 2018) and industrial activity (Dimitrova et al. 1998), though most often the all types of anthropogenic pressure occur (Dassenakis et al. 1998), and the environment is characterized by the comprehensive pollution (Rzetala et al. 2011). However, it is worth emphasizing that the water flow through dam reservoirs 
often causes an improvement in its quality (Jagus and Rzetala 2012).

It rarely happens that dam reservoir collects water from the catchment with a natural or seminatural character (the area without clear human influence). These conditions most often concern the reservoirs, which are located in uninhabited mountain areas. It is usually assumed that the quality of the collected water is then very good. The aim of the research described in this article was to verify the given assumption. In turn, the subject of the research was the Wapienica dam reservoir, which is situated in mountainous regions of southern Poland (Polish Carpathians) in the valley of the Wapienica stream, near the Bielsko-Biala city. The catchment of the reservoir is treated as semi-natural, because within its borders the only works related to forest management are carried out. The research included the identification of physicochemical parameters of the reservoir water, as well as the determination of the water trophy based on the phytoplankton analysis. This enabled a comprehensive evaluation of the water quality.

\section{THE CATCHMENT OF THE WAPIENICA RESERVOIR}

The catchment of the Wapienica reservoir is a mountain catchment and it covers the area of $11.1 \mathrm{~km}^{2}$ (Figure 1). It is located in the western part of the Polish Carpathians. The catchment is cone-shaped and the divide runs through the following peaks: Szyndzielnia (1028 m a.s.1.), Klimczok (1117 m a.s.1.), Stolow (1035 m a.s.1.), Blatnia (917 $\mathrm{m}$ a.s.1.). The area of the catchment slopes down northerly and the water table in the reservoir is at about $470 \mathrm{~m}$ a.s.1. The minimum level of water damming is $463 \mathrm{~m}$ a.s.1. Water flows from the catchment mainly with two streams: Blatnia and Barbara, which flow into the reservoir. They provide about $25,000 \mathrm{~m}^{3}$ of water per day on average (Wiezik et al. 2000). The rest of the catchment, with area of $1.16 \mathrm{~km}^{2}$, is not relevant for feeding of the reservoir.

Wapienica reservoir is currently administered and used by the water supply and sewerage company AQUA S.A. The dam was built between 1928 and 1932 (the coordinates for the dam are as follows: 49 $46^{\prime} 22^{\prime \prime} \mathrm{N} ; 8^{\circ} 51^{\prime} 22^{\prime \prime} \mathrm{E}$ ). This is one of the oldest concrete dams in Europe. Previously, the water for the Bielsko-Biala city came from draining intakes in the Wapienica valley and the numerous municipal wells. When the reservoir is filled to the maximum (water table at the height of $477.6 \mathrm{~m}$ a.s.1.), its surface area is $17.5 \mathrm{ha}$ and capacity 1.05 million $\mathrm{m}^{3}$. The average depth of the reservoir is $8 \mathrm{~m}$ and maximum $-20 \mathrm{~m}$.

The area of the catchment is almost completely $(90 \%)$ covered with woods (the rest of the catchment are grassland areas). The forest cover consists mainly of spruce woods, fir-spruce woods, acid Carpathian beech wood, fertile Carpathian beech wood and mountain sycamore wood. Small treeless areas are a result of the forest being destroyed by wind. These areas are forested by the Bielsko-Biala Forest Inspectorate, which is the owner of the forests in the catchment. The following facts regarding human activities indicate negligible anthropogenic impacts on the catchment environment:

- all forest works are carried out according to the principles of sustainable forest management;

- there is only one household within the catchment - a forester's lodge;

- little-frequented walking-cycling route runs in the central part of the catchment and walking tourist routes run along the divide;

- it is forbidden to drive a private car within the catchment;

- the reservoir is not accessible for recreation (swimming, sunbathing).

Thus, it is justifiable to conclude that there are no significant sources of the contamination in the catchment of the reservoir.

\section{METHODS}

The research was conducted in 2015. The water for analyses was collected from two points - one point was located in the upper part of the reservoir (in the Blatnia and Barbara stream feeding area) and the second point was located near the dam (Figure 1).

The physicochemical and sanitary parameters were analyzed within the state environmental monitoring framework - the water for analyses came from the part near the dam. The following parameters of water were obtained from the Voivodship Inspectorate of Environmental Protection: reaction, suspension, conductivity, dissolved oxygen, $\mathrm{BOD}_{5}, \mathrm{COD}_{\mathrm{Cr}}$, organic carbon, chlorides, sulphates, ammonia, nitrates and 


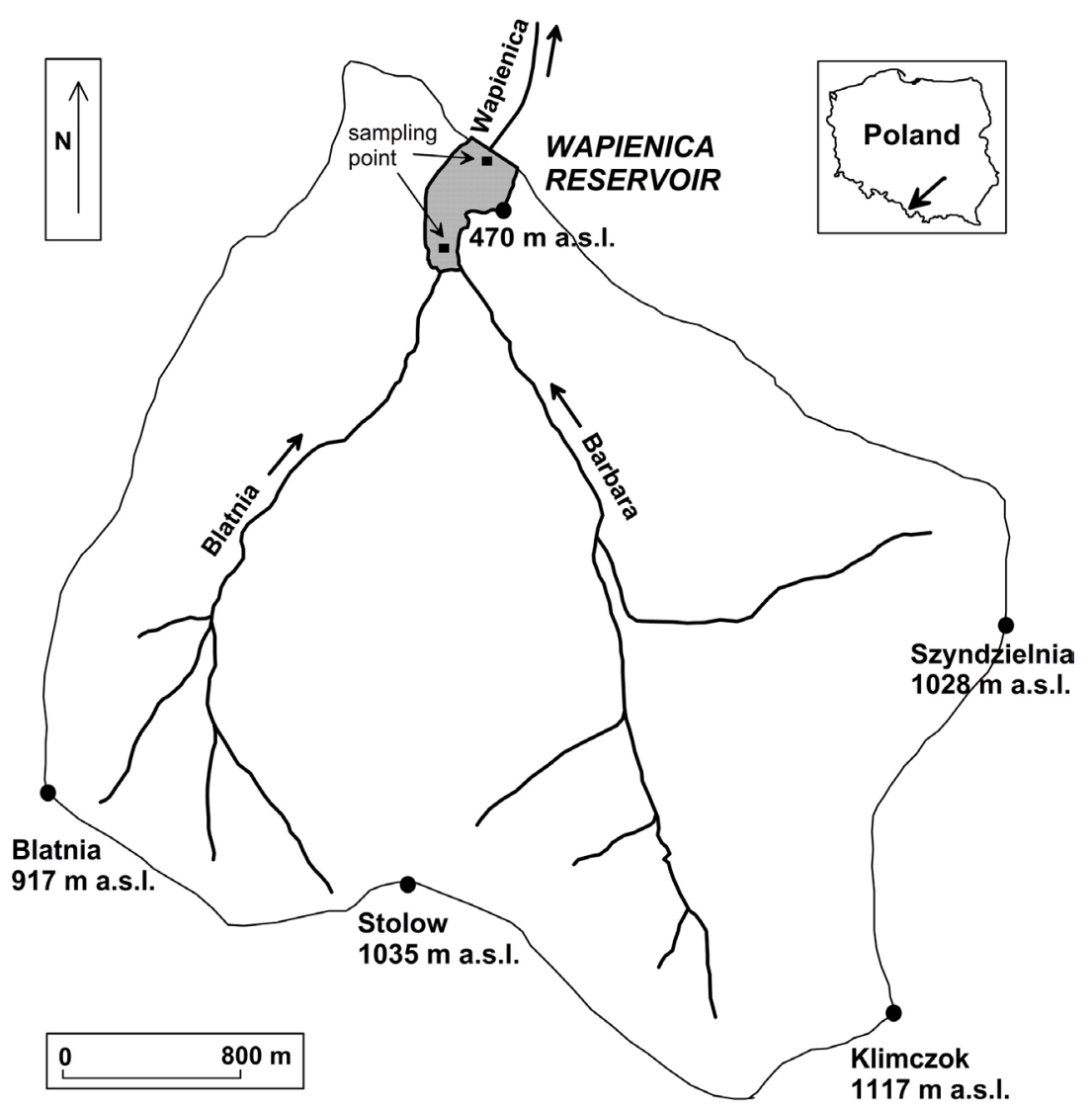

Figure 1. The catchment of the Wapienica dam reservoir

phosphates (12 measurement series), also: iron, manganese, arsenic, chromium, zinc, cadmium, lead, mercury, nickel, Coli group bacteria, fecal coliforms and enterococci ( 8 measurement series). The analyses were carried out in the accredited laboratory (management system PN-EN ISO/ ICE 17025:2005) according to ISO norms.

The trophy status was diagnosed on the basis of the own water analyses, which was taken from the upper part and the part near the dam of the reservoir. The concentration of chlorophyll $a$, the mass of phytoplankton and its species structure were determined. They were determined 5 times in the period from spring to autumn. The water samples were taken from a depth of $1 \mathrm{~m}$ by using the bathometer.

The chlorophyll $a$ content was determined spectrophotometrically by using acetone chlorophyll extract and glass fiber filters (Whatman company, type GF / C), in accordance with the Polish Standard PN-86/C-05560.02. In this method, a defined amount of water sample with seston is filtered through a fiberglass filter, subsequently the filter with seston is rubbed using a grinder. The solution of acetone $(9 \mathrm{ml})$ and distilled water
$(1 \mathrm{ml})$ was used for pulping. The pigments are extracted during the grinding. This extract is given to the refrigerator for 24 hours in order to further extraction of the chlorophyll $a$. This extract is centrifuged and the absorbance of this extract is measured using a spectrophotometer on the second day.

The analyses of the phytoplankton biomass required the preparation of the samples. The phytoplankton samples were concentrated by decanting and sedimentation (during 48 hours) to $1 \mathrm{dm}^{3}$ and then up to $100 \mathrm{~cm}^{3}$. If the sludge size of $100 \mathrm{~cm}^{3}$ compacted sample was greater than $0.2 \mathrm{~cm}^{3}$, this sample was then concentrated to $10 \mathrm{~cm}^{3}$. In turn, if the sludge size was less than $0.2 \mathrm{~cm}^{3}$, this sample was compacted to $5 \mathrm{~cm}^{3}$. During the compaction (in dark glass bottles), the samples were preserved with Lugol liquid in the amount of 30 drops per $\mathrm{dm}^{3}$.

The amount of the biomass and the species composition of the phytoplankton were determined on the basis of the microscopic observations (Lund et al. 1958). The single cells, cenobium or colony were accepted as a unit (specimen) of the phytoplankton, while in filamentous 
algae the length of the filament of $100 \mu \mathrm{m}$ was treated as a unit (specimen) of the phytoplankton. The chamber with a height of $0.4 \mathrm{~mm}$ and a diameter of $20 \mathrm{~mm}$ was used for the analysis. The algae were calculated in 15-27 view fields, in three repetitions.

The amount of the phytoplankton biomass (given in wet mass) was calculated by comparison the phytoplankton organisms to geometric figures (Rott 1981). The determination of the species composition was made on the basis of the appropriate keys (Starmach 1989, Hindak 1996).

\section{RESULTS AND DISCUSSION}

\section{Physicochemical parameters}

The results pertaining to the physicochemical analyses of the reservoir water prove that it is of good quality. The values of the parameter generally corresponded to the levels characteristic for clean water (Dojlido 1995) and they also were within the limits of the Polish standards for supplying water (Ordinance... 2002) (Table 1). The low $\mathrm{BOD}_{5}$ values (maximum $3 \mathrm{mgO} \cdot \mathrm{dm}^{-3}$ ) and $\mathrm{COD}_{\mathrm{Cr}}$ (maximum $11 \mathrm{mgO} \cdot \mathrm{dm}^{-3}$ ) expressed the presence of a small amount of the organic matter. The high dissolved oxygen content (average $9 \mathrm{mgO}_{2} \cdot \mathrm{dm}^{-3}$ ) indicated good conditions for the decomposition of the organic pollutants, although during the short periods (in the middle of summer) it was unsatisfactory. In the case of the dissolved mineral substances, the electrical conductivity of water is a good indicator of their occurrence. Its values in the range of 60-80 $\mu \mathrm{S} \cdot \mathrm{cm}^{-1}$ indicated a very low content of these substances. The chlorides and sulphates occurred in small amounts (less than $4 \mathrm{mgCl} \cdot \mathrm{dm}^{-3}$ and less than $13 \mathrm{mgSO}_{4}^{2-} \cdot \mathrm{dm}^{-3}$ ), also biogenic compounds of the nitrogen and phosphorus occurred in small amounts. Nitrates (V) were recorded in a maximum amount of $5.1 \mathrm{mgNO}_{3}^{-\cdot} \cdot \mathrm{dm}^{-3}$, while phosphates were not detected (sensitivity of the method above $0.05 \mathrm{mgPO}_{4}^{3-\cdot} \cdot \mathrm{dm}^{-3}$ ). The ammonia was also recorded at low concentrations and only once the concentration exceeded the value of 0.5 $\mathrm{mgNH}_{4}^{+} \cdot \mathrm{dm}^{-3}$. This is the value defined as the limit for clean water (Dojlido 1995).

The presence of micro-pollutants, particularly trace metals constitute a good indicator of the anthropogenic pressure on the environment.

Table 1. Qualitative parameters of Wapienica reservoir water in the 2015 year compared to values for clean water (Dojlido 1995) and requirements for supplying water (Ordinance... 2002)

\begin{tabular}{|c|c|c|c|c|}
\hline Parameter & Unit & $\begin{array}{l}\text { Value range } \\
\text { for Wapienica } \\
\text { reservoir water }\end{array}$ & $\begin{array}{c}\text { Value range } \\
\text { for clean natural } \\
\text { water }\end{array}$ & $\begin{array}{l}\text { Polish requirements } \\
\text { for supplying water } \\
\text { (best category level) }\end{array}$ \\
\hline Reaction & $\mathrm{pH}$ & $6.7-7.7$ & $6.0-8.5$ & $6.5-8.5$ \\
\hline Suspension & $\mathrm{mg} \cdot \mathrm{dm}^{-3}$ & $\leq 13$ & $<25$ & $<25$ \\
\hline Conductivity & $\mu \mathrm{S} \cdot \mathrm{cm}^{-1}$ & $58-82$ & $<200$ & $<1000$ \\
\hline Dissolved oxygen & $\mathrm{mgO}_{2} \cdot \mathrm{dm}^{-3}$ & $2.4-12.0$ & $>8$ & no restrictions \\
\hline $\mathrm{BOD}_{5}$ & $\mathrm{mgO}_{2} \cdot \mathrm{dm}^{-3}$ & $0.6-3.0$ & $<3$ & $<3$ \\
\hline $\mathrm{COD}_{\mathrm{Cr}}$ & $\mathrm{mgO}_{2} \cdot \mathrm{dm}^{-3}$ & $\leq 11$ & $<25$ & $<25$ \\
\hline Organic carbon & $\mathrm{mgC} \cdot \mathrm{dm}^{-3}$ & $\leq 3.7$ & a few & $<5$ \\
\hline Chlorides & $\mathrm{mgCl}^{-} \cdot \mathrm{dm}^{-3}$ & $1.58-3.86$ & $<200$ & $<250$ \\
\hline Sulphates & $\mathrm{mgSO}_{4}{ }^{2-} \cdot \mathrm{dm}^{-3}$ & $6.9-12.6$ & $<150$ & $<250$ \\
\hline Ammonia & $\mathrm{mgNH}_{4}^{+} \cdot \mathrm{dm}^{-3}$ & $\leq 0.52$ & $<0.5$ & $<0.5$ \\
\hline Nitrates(V) & $\mathrm{mgNO}_{3}^{-\cdot} \cdot \mathrm{dm}^{-3}$ & $\leq 5.1$ & $<10$ & $<50$ \\
\hline Phosphates & $\mathrm{mgPO}_{4}{ }^{3-} \cdot \mathrm{dm}^{-3}$ & $<0.05$ & $<0.2$ & $<0.4$ \\
\hline Iron & $\mathrm{mgFe} \cdot \mathrm{dm}^{-3}$ & $\leq 0.12$ & $<1$ & $<0.3$ \\
\hline Manganese & $\mathrm{mgMn} \cdot \mathrm{dm}^{-3}$ & $\leq 0.09$ & $<0.1$ & $<0.05$ \\
\hline Arsenic & $\mathrm{mgAs} \cdot \mathrm{dm}^{-3}$ & $<0.01$ & $<0.001$ & $<0.05$ \\
\hline Chromium $\left(\mathrm{Cr}^{3+}+\mathrm{Cr}^{6+}\right)$ & $\mathrm{mgCr} \cdot \mathrm{dm}^{-3}$ & $<0.003$ & $<0.02$ & $<0.05$ \\
\hline Zinc & $\mathrm{mgZn} \cdot \mathrm{dm}^{-3}$ & $\leq 0.13$ & $<0.015$ & $<3$ \\
\hline Cadmium & $\mu \mathrm{gCd} \cdot \mathrm{dm}^{-3}$ & $\leq 0.06$ & $<0.15$ & $<5$ \\
\hline Lead & $\mu \mathrm{gPb} \cdot \mathrm{dm}^{-3}$ & $<2$ & $<3$ & $<50$ \\
\hline Mercury & $\mu \mathrm{gHg} \cdot \mathrm{dm}^{-3}$ & $\leq 0.03$ & $<0.2$ & $<1$ \\
\hline Nickel & $\mu \mathrm{gNi} \cdot \mathrm{dm}^{-3}$ & $<5$ & $<3$ & $<50$ \\
\hline
\end{tabular}


The trace metals were present in the reservoir water in negligible amounts, with the exception of the zinc (Table 1). The average concentration of the zinc was $0.022 \mathrm{mgZn} \cdot \mathrm{dm}^{-3}$, and the maximum was $0.131 \mathrm{mgZn} \cdot \mathrm{dm}^{-3}$, meanwhile, it is reported that this metal exerts the toxic effect on fish already at a concentration of $0.100 \mathrm{mgZn} / \mathrm{dm}^{3}$ (Moore and Ramamoorthy 1984). The presence of zinc in surface water results, i.a. from its very high mobility in the soil environment (compared to other metals) (Dostatni et al. 2009, Jagus and Skrzypiec 2019). A possible source of zinc and other metals in the soils of Wapienica reservoir catchment might be the atmosphere, because deposition of atmospheric substances concerns even areas, which are located far from emitters (Kyllonen et al. 2009). The contaminants that might enter the area of the catchment can derive from the nearby industrial regions: Upper Silesian in Poland and Ostravian in the Czech Republic.

\section{Sanitary parameters}

The bacteria of the Coli group were observed in the water of the Wapienica reservoir - an average of 324 cells in $100 \mathrm{~cm}^{3}$, while a maximum of 2098 cells. The bacteria of the Coli group are divided into two basic types: the fecal type represented by Escherichia coli and the earth type, for which the indicator organism is Enterobacter aerogenes. According to the Polish standards qualifying water for consumption (Ordinance... 2017), the Escherichia coli cannot be present in such water. This bacterium was found in the water of the reservoir in the maximum amount 52 cells in $100 \mathrm{~cm}^{3}$. The analyses also showed the occurrence of individual enterococci (maximally 3 cells in $100 \mathrm{~cm}^{3}$ of water), which also disqualify water for the drinking purposes. These bacteria occur in the water of the reservoir can come from animal excrement and soil.

The water from the reservoir is treated before it is pumped to the water supply network. The administrator of the water supply mains AQUA S.A. guarantees that all quality requirements for treated water (especially microbiological indicators) are met. Water leaves the dam through a 500-mm pipe to the treatment station. First, it reaches distribution channels. These channels distribute water to 12 filtration chambers. Each chamber has an anthracite-sand filter. Its upper part is a 0.6-metre-thick layer anthracite, grain size $0.8-2.0 \mathrm{~mm}$, and the lower part, also 0.6-metre-thick is made of silica sand, grain size $0.6-0.8 \mathrm{~mm}$. After filtration, water flows gravitationally to the water mains. Water is disinfected in draining pipes using sodium hypochlorite, which is produced from salt in the treatment station. Water solution of sodium hypochlorite $(0.6 \%$ solution $)$ is dosed by three pumps. Up to $50,000 \mathrm{~m}^{3}$ of water can be disinfected per day.

\section{Trophic parameters}

Very low content of the nitrates and phosphates in the reservoir water indicates on its low trophic status (the low fertility). This opinion is worth verifying by analyzing the parameters, which reveal biological production, i.e. the

Table 2. Values of the trophic parameters of water - Wapienica dam reservoir, 2015 year

\begin{tabular}{|c|c|c|c|}
\hline Parameter & $\begin{array}{c}\text { Measurement } \\
\text { series no. }\end{array}$ & $\begin{array}{c}\text { Upper part } \\
\text { of the reservoir }\end{array}$ & $\begin{array}{l}\text { Dam zone } \\
\text { of the reservoir }\end{array}$ \\
\hline \multirow{5}{*}{$\begin{array}{c}\text { Chlorophyll a } \\
\text { concentration } \\
{\left[\mu \mathrm{g} \cdot \mathrm{dm}^{-3}\right]}\end{array}$} & 1 & 0.45 & 3.56 \\
\hline & 2 & 0.44 & 20.05 \\
\hline & 3 & 0.89 & 7.35 \\
\hline & 4 & 0.38 & 17.37 \\
\hline & 5 & 0.67 & 2.27 \\
\hline \multirow{5}{*}{$\begin{array}{c}\text { Phytoplankton } \\
\text { biomass amount } \\
{\left[\mathrm{mg} \cdot \mathrm{dm}^{-3}\right]}\end{array}$} & 1 & 0.05 & 0.89 \\
\hline & 2 & 0.23 & 14.09 \\
\hline & 3 & 1.44 & 2.63 \\
\hline & 4 & 1.04 & 1.85 \\
\hline & 5 & 0.55 & 2.34 \\
\hline \multirow{5}{*}{$\begin{array}{l}\text { Dominant group } \\
\text { of phytoplankton } \\
\text { organisms }\end{array}$} & 1 & Cryptophyta and Diatoms & Dinophyta \\
\hline & 2 & Diatoms & Dinophyta \\
\hline & 3 & Diatoms & Dinophyta \\
\hline & 4 & Diatoms & Diatoms \\
\hline & 5 & Diatoms & Diatoms \\
\hline
\end{tabular}


chlorophyll $a$, concentration and the amount and quality of the growing phytoplankton. The values of these parameters determined in the research are given in Table 2.

The trophic classification of the reservoir water according to chlorophyll $a$ content groups the reservoirs as (Heinonen 1980):

- oligotrophic (lowest fertility) $\rightarrow$ less than $2.5 \mu \mathrm{g} \cdot \mathrm{dm}^{-3}$

- mesotrophic $\rightarrow 2.5-8.0 \mu \mathrm{g} \cdot \mathrm{dm}^{-3}$;

- eutrophic $\rightarrow 8.1-25.0 \mu \mathrm{g} \cdot \mathrm{dm}^{-3}$;

- hypertrophic (highest fertility) $\rightarrow$ above $25 \mu \mathrm{g} \cdot \mathrm{dm}^{-3}$.

The conducted analyses of the chlorophyll $a$ concentration in the water of the Wapienica reservoir (Table 2) indicate that in the upper part of the reservoir had a constantly oligotrophic character. It is a part, which is fed by cool water of the mountain streams. The part of the reservoir near the dam was exposed to the Sun's rays and possessed periodically features of both oligotrophy and mesotrophy, and even eutrophy.

The amount of the phytoplankton biomass in the water of the Wapienica reservoir (Table 2) reflected the chlorophyll $a$ concentrations. In the upper part of the reservoir the phytoplankton biomass remained at the oligotrophy level, although in one series $\left(1.44 \mathrm{mg} \cdot \mathrm{dm}^{-3}\right)$ it increased to the mesotrophy level. The conditions occurring in the part of the reservoir near the dam allowed the growth of phytoplankton in the average amount of $4.3 \mathrm{mg} \cdot \mathrm{dm}^{-3}$. In this part of the reservoir the mesotrophy and mesoeutrophy status dominated and $\left(14.09 \mathrm{mg} \cdot \mathrm{dm}^{-3}\right)$ an advanced eutrophy occurred once.

The development of the phytoplankton in the considered reservoir was heterogeneous not only in respect of the biomass amount, but also its species composition (Table 2). In the upper part of the reservoir in the first measurement series (spring series) the Cryptophyta and Bacillariophyceae occurred in a similar share (about $50 \%$ each) and in the next series definitely Bacillariophyceae dominated. The diatoms species occurring in this part (Achnanthes lanceolata, Tabellaria flocullosa, Encyonema sp., Eunotia sp.) prefer the oxygenated oligotrophic and oligomesotrophic water (Keatley et al. 2009). In the part of the reservoir near the dam the dominance of Dinophyceae was found in the spring and summer period, while in the autumn period the dominance of Bacillariophyceae was observed. Among the dinophyta, Ceratium hirundinella was distinguished by abundance. This taxon is characteristic for mesotrophic water with a low content of the organic substances. In turn, among the diatoms, Nitzschia acicularis was observed in large numbers. It most often develops under mesotrophic and slightly eutrophic conditions (Bucka and Wilk-Wozniak 2007).

High biological productivity in the lower part of the reservoir indicates the symptoms of the eutrophication process. It is surprising in a forested mountain area. This problem can be related with low water level and serious silting of the reservoir bowl. It is possible to obtain nutrients (especially phosphates) from the bottom sediments into the water. Shallowing the silted reservoir and as a consequence the water heating are additional factors, which favor the development of the phytoplankton. The development of the eutrophication process is a threat to the reservoir, because it will cause the accumulation of the organic matter. In perspective, it can lead to the contamination of water with organic compounds and increase its fertility (the content of the nitrogen and phosphorus mineral compounds).

\section{CONCLUSIONS}

1. The water retained in the Wapienica reservoir, which flows from the mountain forest catchment, is characterized by favourable physicochemical parameters. Pollution can be related with the very mobile substances in the soil environment, which easily infiltrate into the water, such as the zinc.

2. The possibility of occurrence in water of the microorganisms, which pose a sanitary threat should be taken into account even in the uninhabited area.

3. The reservoir is not homogeneous in terms of the biological productivity. In the upper part the reservoir has oligotrophic status. In the lower part (in the part of the reservoir near the dam) the fertility of the water is higher - the mesotrophy level prevails, and mesoeutrophy and eutrophy occur periodically.

4. The research indicates that even in reservoirs, which function in semi-natural mountain conditions there may be problems with water quality. Continuous protection of such reservoirs and current recultivation treatments are needed, e.g. sediments removal. 


\section{REFERENCES}

1. Bucka H., Wilk-Wozniak E. 2007. Pro- and eukaryotic algae of phytoplankton communities in water reservoirs in southern Poland, Published by IOP PAN, Krakow (in Polish).

2. Cao Z.J, Zhang X.B., Ai N.S. 2011. Effect of sediment on concentration of dissolved phosphorus in the Three Gorges Reservoir. International Journal of Sediment Research, 26(1), 87-95.

3. Cheung K.C., Poon B.H.T, Lan C.Y., Wong M.H. 2003. Assessment of metal and nutrient concentrations in river water and sediment collected from the cities in the Pearl River Delta, South China. Chemosphere, 52(9), 1431-1440.

4. Dabrowski J., Oberholster P.J., Dabrowski J.M. 2014. Water quality of Flag Boshielo Dam, Olifants River, South Africa: Historical trends and the impact of drought. Water SA, 40(2), 345-357.

5. Dassenakis M., Scoullos M., Foufa E., Krasakopoulou E., Pavlidou A., Kloukiniotou M. 1998. Effects of multiple source pollution on a small Mediterranean river. Applied Geochemistry, 13(2), 197-211.

6. Dimitrova I., Kosturkov J., Vatralova A. 1998. Industrial surface water pollution in the region of Devnya, Bulgaria. Water Science \& Technology, 37(8), 45-53.

7. Dojlido J.R. 1995. Chemistry of surface waters. Published by Ekonomia i Srodowisko, Bialystok (in Polish).

8. Dostatni A., Troc M., Wojtasik A., Lecki P. 2009. Heavy metals concentration in forest soils from the interfluvial terrain between Warta and Notec Rivers. Ekologia i Technika, 17(3), 104-108 (in Polish).

9. Heinonen P. 1980. Quantity and composition of phytoplankton in Finnish inland waters. Publications of Water Research Institute, 37, Helsinki.

10. Hindak F. 1996. Key to the unbranched filamentous green algae (Ulotrichineae, Ulotrichales, Chlorophyceae). Bulletin Slovenskej Botanickej Spolocnosti Pri Sav, Suppl. 1, 1-77.

11. Jagus A., Rzetala M. 2012. Hydrochemical consequences of feeding flow-through reservoirs with contaminated water. Rocznik Ochrona Srodowiska, 14, 632-649.

12. Jagus A., Skrzypiec M. 2019. Toxic elements in mountain soils (Little Beskids, Polish Carpathians). Journal of Ecological Engineering, 20(1), 197-202.

13. Keatley B.E., Douglas M.S.V., Blais J.M., Mallory M.L., Smol J.P. 2009. Impacts of seabird-derived nutrients of water quality and diatom assemblages from Cape Vera, Devon Island, Canadian High Arctic. Hydrobiologia, 621, 191-205.

14. Kyllonen K., Karlsson V., Ruoho-Airola T. 2009. Trace element deposition and trends during a ten year period in Finland. Science of the Total Envi- ronment, 407, 2260-2269.

15. Lugo A., Bravo-Incla L.A., Alcocer J., Gaytan M.L., Oliva M.G., Sanchez M.R., Chavez M., Vilaclara G. 1998. Effect on the planktonic community of the chemical program used to control water hyacinth (Eichhornia crassipes) in Guadalupe Dam, Mexico. Aquatic Ecosystem Health and Management, 1, 333-343.

16. Lund J.W.G., Kipling C., Le Gren E.D. 1958. The inverted microscope method of estimating algal numbers and the statistical basis of estimation by counting. Hydrobiologia, 1, 144-170.

17. Melland A.R., Fenton O., Jordan P. 2018. Effects of agricultural land management changes on surface water quality: A review of meso-scale catchment research. Environmental Science \& Policy, $84,19-25$.

18. Moore J., Ramamoorthy S. 1984. Heavy metals in natural waters, Published by Springer-Verlag, Berlin.

19. Ordinance of the Polish Minister of Environment dated 27 November 2002 on the requirements to be met by surface water used for supply of population in water intended for consumption. 2002. DzU 2002 Nr 204 Poz 1728, Ministry of Environment, Warszawa (in Polish).

20. Ordinance of the Polish Minister of Health dated 29 December 2017 on the quality of drinking water. 2017. DzU 2017 Poz 2294, Ministry of Health, Warszawa (in Polish).

21. Rott E. 1981. Some results from phytoplankton counting intercalibrations. Schweizerische Zeitschrift fur Hydrologie, 43(1), 34-62.

22. Rzetala M.A., Rahmonov O., Jagus A., Rahmonov M., Rzetala M., Machowski R. 2011. Occurrence of chemical elements in common reeds (Phragmites australis) as indicator of environmental conditions. Research Journal of Chemistry and Environment, 15(2), 610-616.

23. Sim S.F., Ling T.Y., Nyanti L., Gerunsin N., Wong Y.E., Kho L.P. 2016. Assessment of heavy metals in water, sediment and fishes of a large tropical hydroelectric dam in Sarawak. Journal of Chemistry, article no. 8923183.

24. Starmach K. 1989. Freshwater planktonic - research methods and keys for the determination of species found in the Central Europe. Published by PWN, Warszawa - Krakow (in Polish).

25. Tarkowska-Kukuryk M. 2013. Effect of phosphorus loadings on macrophytes structure and trophic state of dam reservoir on a small lowland river (eastern Poland). Archives of Environmental Protection, 39(3), 33-46.

26. Wiezik B., Bojarski A., Stonawski J., Franik H. 2000. The maintenance and operation of the Wapienica storage water reservoir. Published by AQUA S.A. and HYDRO-consult s.c., Bielsko-Biala Kozy (in Polish). 